\title{
Aerosol Optical Depth Retrieval over Bright Areas Using Landsat 8 OLI Images
}

\author{
Lin Sun ${ }^{1}$, Jing Wei ${ }^{1, *}$, Muhammad Bilal ${ }^{2}$, Xinpeng Tian ${ }^{1}$, Chen Jia ${ }^{1}$, Yamin Guo ${ }^{3}$ and \\ Xueting Mi ${ }^{1}$
}

Received: 30 June 2015; Accepted: 25 December 2015; Published: 31 December 2015

Academic Editors: Alexander A. Kokhanovsky and Prasad S. Thenkabail

1 Geomatics College, Shandong University of Science and Technology, Shandong, Qingdao 266590, China; sunlin6@126.com (L.S.); tian_xp@163.com (X.T.); jiachen_1991@163.com (C.J.); mixueting@yeah.net (X.M.)

2 Department of Land Surveying and Geo-Informatics, the Hong Kong Polytechnic University, Hung Hom, Kowloon 999077, Hong Kong; muhammad.bilal@connect.polyu.hk

3 School of Geography, Beijing Normal University, Beijing 100875, China; guoym_gis@163.com

* Correspondence: weijing_rs@163.com; Tel.: +86-532-8803-2922

\begin{abstract}
Conventional methods for Aerosol Optical Depth (AOD) retrieval are limited to areas with low reflectance such as water or vegetated areas because the satellite signals from the aerosols in these areas are more obvious than those in areas with higher reflectance such as urban and sandy areas. Land Surface Reflectance (LSR) is the key parameter that must be estimated accurately. Most current methods used to estimate AOD are applicable only in areas with low reflectance. It has historically been difficult to estimate the LSR for bright surfaces because of their complex structure and high reflectance. This paper provides a method for estimating LSR for AOD retrieval in bright areas, and the method is applied to AOD retrieval for Landsat 8 Operational Land Imager (OLI) images at $500 \mathrm{~m}$ spatial resolution. A LSR database was constructed with the MODerate-resolution Imaging Spectroradiometer (MODIS) surface reflectance product (MOD09A1), and this database was also used to estimate the LSR of Landsat 8 OLI images. The AOD retrieved from the Landsat 8 OLI images was validated using the AOD measurements from four AErosol RObotic NETwork (AERONET) stations located in areas with bright surfaces. The MODIS AOD product (MOD04) was also compared with the retrieved AOD. The results demonstrate that the AOD retrieved with the new algorithm is highly consistent with the AOD derived from ground measurements, and its precision is better than that of MOD04 AOD products over bright areas.
\end{abstract}

Keywords: AOD; bright surfaces; Landsat 8 OLI; AERONET; MOD04

\section{Introduction}

Aerosols are colloids of solid particles or liquid droplets suspended in the atmosphere; their diameters range from $10^{-3}$ to $10^{2}$ micrometers. They affect the global climate in direct and indirect ways by absorbing and scattering solar radiation and can also seriously influence human health by spreading harmful substances [1-6].

The development of satellite remote sensing technologies has facilitated dynamic real-time aerosol monitoring on a large scale. Several methods for Aerosol Optical Depth (AOD) retrieval of passive radiometric radiances have been developed over the past 40 years. Among these, the Dense Dark Vegetation (DDV) method was the first and has proved to be the most popular. It has been widely used to retrieve AOD in areas with dense vegetation based on data from satellite sensors, such as AVHRR (Advanced Very High Resolution Radiometer) [7], SeaWiFS (Sea-viewing Wide Field of view Sensor) [8], and MODIS (MODerate resolution Imaging Spectroradiometer) $[9,10]$. Dense vegetation has a lower reflectance in the blue and red bands compared with other land cover types with high 
reflectance. The ratios of satellite signals contributed by the aerosol in these two bands are relatively higher. Aerosol information can be retrieved with high precision in such areas [11-13].

The primary step for AOD retrieval with the DDV method is the determination of Land Surface Reflectance (LSR) from passive radiometric inversions. Many methods have been developed since this method was first presented [14] wherein the Normalized Difference Vegetation Index (NDVI) is used to identify dense vegetation pixels. If the NDVI for a pixel exceeds a given value, the pixel is defined as dense vegetation, which is used for AOD retrieval [11,14]. However, NDVI rapidly decreases with increasing AOD (Figure 1). Thus, it is difficult to find DDV pixels if the AOD is greater than a certain threshold value [11].

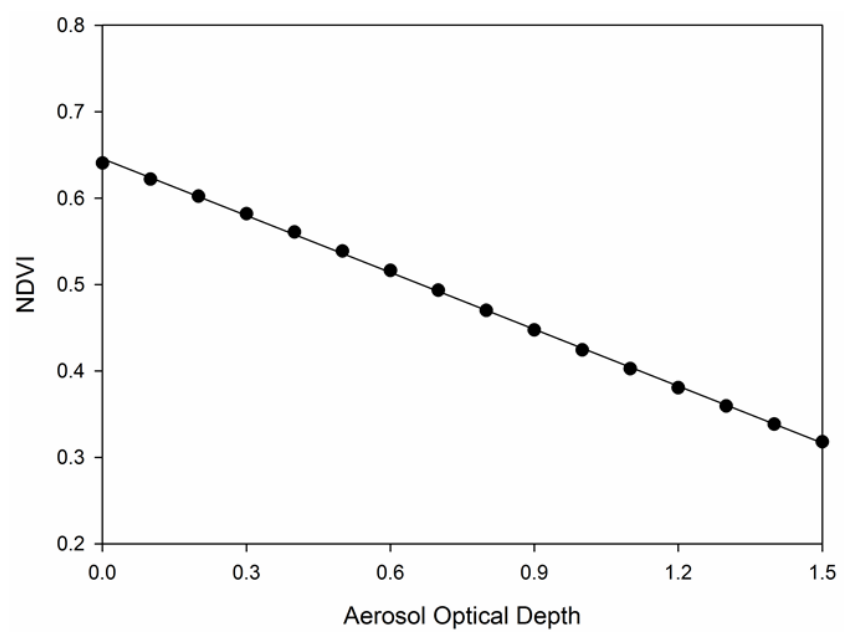

Figure 1. The Normalized Difference Vegetation Index (NDVI) at the reflectance at the top of the atmosphere (TOA) as a function of the Aerosol Optical Depth (AOD) at $550 \mathrm{~nm}$, demonstrating that the NDVI is strongly influenced by aerosols.

Based on studies of land reflectance using ground measurement and airborne sensors, it was found that the reflectance of vegetation at $2.1 \mu \mathrm{m}$ is correlated with reflectance in the red and blue bands that are used for aerosol retrieval. Under most conditions, with the exception of dust storms, aerosols are almost transparent at that wavelength, and the reflectance of the red and blue bands can be easily estimated from its apparent reflectance [12]. This method has since been improved and used for AOD retrieval from multiple satellite sensors [12,13,15-18].

The DDV method can be used to retrieve the AOD with high precision over land with dense vegetation cover, but the method does not work over bright areas such as cities and other areas with little or no vegetation cover [19]. In these regions, the land surface contribution to the radiance received by a satellite is larger than that over vegetated areas, so it is difficult to estimate LSR with high precision. To accomplish AOD retrieval in such areas, a structure function method (also known as the contrast reduction method) was proposed that uses a blurring effect to retrieve the AOD over bright surfaces [20]. This method estimates AOD based on the differences in reflectance between two adjacent pixels. The structure function method has been applied in various bright areas with high accuracy $[21,22]$. However, to provide a reference structure function value, a clear image close to the object image is required. In most bright areas, it is difficult to acquire a clear image that meets these requirements, which seriously limits its practical application.

Studies have focused on high-resolution satellite aerosol retrievals, including the MAIAC (Multi-Angle Implementation of Atmospheric Correction) algorithm [23] and SARA (Simplified Aerosol Retrieval Algorithm) [24,25]. These methods specifically aim to retrieve more accurate surface reflectance from MODIS data, thereby improving AOD retrieval at high spatial resolutions.

In areas that are not covered by dense vegetation, such as desert areas, the reflectance in the blue band $(412 \mathrm{~nm})$ is relatively higher than that over vegetated areas. However, this reflectance is still 
relatively low, allowing AOD retrieval at a reasonable precision when the surface reflectance can be accurately determined over this type of surface. This advance led to the retrieval of AOD in the Sahara Desert $[26,27]$. In areas where land cover is complex, accurate estimation of LSR is very challenging. In this paper, a new method for AOD retrieval over urban surfaces from Landsat 8 OLI images based on MODIS surface reflectance products (MOD09) for LSR estimation is proposed. Based on the combined use of these two types of satellite remote sensing data, AOD retrieval can be realized over bright areas.

Landsat and MODIS data have been used jointly in many fields. Landsat satellite data have a high spatial resolution of $30 \mathrm{~m}$ but a long revisiting period of 16 days; in contrast, MODIS data are more highly temporally resolved, generally with two passes per day, but have a low spatial resolution of $250 \mathrm{~m}, 500 \mathrm{~m}$, or $1000 \mathrm{~m}$. Studies that blend the two types of data have mainly focused on the methodology of combining the datasets. Using these data together helps improve the temporal resolution and spatial resolution of land surface or atmospheric parameters [28-30]. For example, aiming to provide continental-scale $30 \mathrm{~m}$ products of the United States, corrected Landsat 7 ETM+ images for atmospheric characterization data were derived from MODIS [31]. Similar to that study, this paper proposes a new algorithm for AOD retrieval from Landsat 8 OLI images supported by MODIS LSR. This algorithm makes use of a prior surface reflectance database that was constructed with a long time series of MODIS LSR data. The algorithm is then used to support the determination of LSR from the Landsat 8 OLI images. Subsequently, AOD retrieval over bright areas can be achieved from Landsat 8 OLI data.

\section{Methods}

\subsection{Principles}

For Lambertain surfaces under a plane-parallel atmosphere, the radiance measured by a satellite sensor can be written as a function of surface reflectance (Equation (1)) as

$$
L\left(\tau_{a}, \mu_{s}, \mu_{v}, \phi\right)=L_{0}\left(\tau_{a}, \mu_{s}, \mu_{v}, \phi\right)+\frac{\rho_{s}}{1-\rho_{s} * S\left(\tau_{a}\right)} \mu_{s} F_{0} T\left(\tau_{a}, \mu_{s}\right) T\left(\tau_{a}, \mu_{v}\right)
$$

where $L$ is the radiance at the top of the atmosphere (TOA), $\tau_{a}$ is the atmospheric optical depth that is produced by gas molecules and aerosol particles, $L_{0}$ is the path radiance that is produced by scattering of particles and molecules in the atmosphere, $S$ is the atmospheric backscattering ratio, $\rho_{S}$ is the surface reflectance, $T\left(\tau_{a}, \mu_{v}\right)$ is the transmittance from the top to the ground, $T\left(\tau_{a}, \mu_{s}\right)$ is the transmittance from the ground to the TOA, $F_{0}$ is the total downward radiance, and $\mu_{s}, \mu_{v}$ and $\varphi$ are the cosine of the solar zenith angle, the cosine of the view zenith angle, and the relative azimuth angle, respectively.

The TOA reflectance received by the satellite sensor comes from the atmosphere and LSR. Equation (1) shows that the TOA radiance increases with decreasing LSR, dominated by the atmospheric path radiance. This is the foundation of the DDV method. However, when the LSR increases, the atmospheric contribution to the TOA radiance decreases, thus complicating the AOD retrieval.

However, the largest component of the satellite signal comes from the land surface, even when the LSR is very low. To retrieve the AOD, the LSR must be estimated accurately. Following the development of the DDV method for AOD retrieval, many methods have been proposed for LSR estimation in the blue and red bands over areas covered by dense vegetation. For low-reflectance land areas, the AOD can be estimated with relatively high accuracy [13,21]. However, in areas with bright surfaces such as arid, semiarid, and urban areas, it is difficult to retrieve the AOD with high accuracy.

Figure 2 shows the relationship between AOD and TOA reflectance simulated by MODTRAN 4 (MODerate spectral resolution atmospheric TRANsmittance algorithm and computer model) in the blue band $(0.47 \mu \mathrm{m})$ under varying surface reflectance. The relationship demonstrates that the TOA reflectance still responds to an increase in the AOD when the surface reflectance is much higher than that for the DDV surfaces, which is usually less than 0.04 in the blue band [11]. Therefore, the AOD 
can be retrieved accurately if the LSR can be estimated accurately. Thus, it is critical to estimate the surface reflectance in such areas.

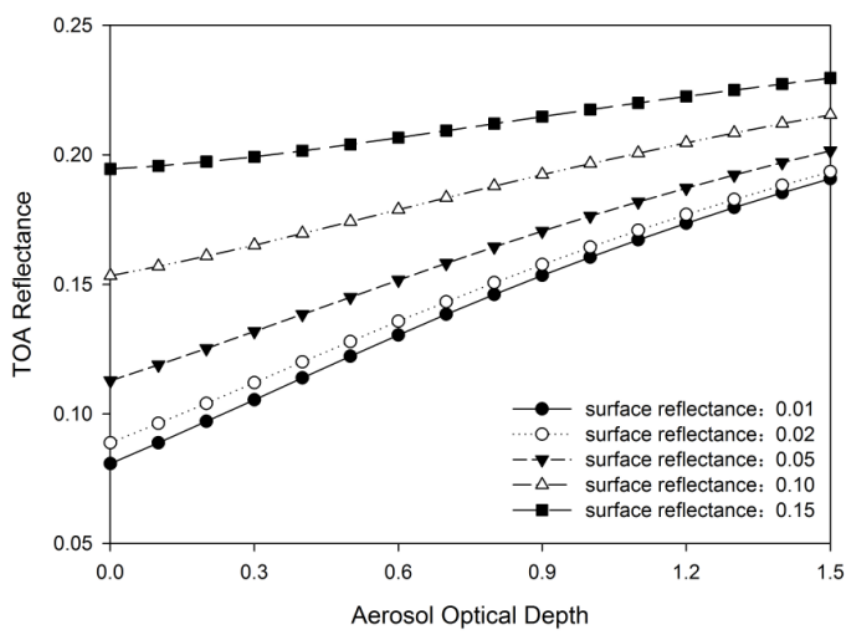

Figure 2. The relationship between AOD and TOA reflectance in the blue band $(0.47 \mu \mathrm{m})$ under different surface conditions.

\subsection{LSR Database Construction}

MOD09A1 data encompassing the entire year of 2012 were collected and processed to support AOD retrieval. MOD09A1 provides bands 1-7 at $500 \mathrm{~m}$ resolution in an eight-day gridded Level-3 product. Each pixel contains the best possible observation during an eight-day period, selected on the basis of high observation coverage, low view angle, the absence of clouds or cloud shadows, and aerosol loading. The datasets provided for this product include the reflectance values of bands $1-7$, quality assessment, and the day of the year for each pixel, along with the solar, view, and zenith angles. The level of accuracy of atmospheric correction is typically $\pm(0.005+0.05 \times$ reflectance $)$ under favorable conditions [32].

To reduce the computation required, a one-month LSR database was created for the AOD retrieval data for that month. The lowest LSR for each pixel in four images was chosen to be the pixel for the one-month series to reduce the impact of cloud and surface contamination.

Corresponding surface reflectance was calculated for four AERONET sites, Beijing (39.977 ${ }^{\circ}$, $\left.116.381^{\circ} \mathrm{E}\right), \mathrm{XiangHe}\left(39.754^{\circ} \mathrm{N}, 116.962^{\circ} \mathrm{E}\right)$, Beijing_CAMS $\left(39.933^{\circ} \mathrm{N}, 116.317^{\circ} \mathrm{E}\right)$ and Beijing_RADI $\left(40.005^{\circ} \mathrm{N}, 116.379^{\circ} \mathrm{E}\right)$. Table 1 shows the difference in the surface reflectance magnitude. The contribution of the land surface to the satellite is greater than that of the atmosphere, even when the land surface reflectance at $555 \mathrm{~nm}$ ranged from 0.045 to 0.09 .

Table 1. The magnitude of the surface reflectance at the four AErosol RObotic NETwork (AERONET) sites on different dates.

\begin{tabular}{lccccc}
\hline \multirow{2}{*}{ Date } & \multirow{2}{*}{ Wavelength $(\mathbf{n m})$} & \multicolumn{3}{c}{ Surface Reflectance at Different AERONET Sites } \\
\cline { 2 - 5 } & & Beijing & XiangHe & Beijing_RADI & Beijing_CAMS \\
\hline \multirow{3}{*}{ May 2012 } & 645 & 0.0914 & 0.1040 & 0.0793 & 0.0933 \\
& 858 & 0.1799 & 0.2494 & 0.2225 & 0.1807 \\
& 470 & 0.0465 & 0.0519 & 0.0387 & 0.0462 \\
June 2012 & 555 & 0.0866 & 0.0935 & 0.0855 & 0.0870 \\
& 645 & 0.0930 & 0.0796 & 0.0654 & 0.0841 \\
& 858 & 0.1660 & 0.2503 & 0.2213 & 0.1779 \\
& 470 & 0.0409 & 0.0420 & 0.0303 & 0.0430 \\
& 555 & 0.0702 & 0.0744 & 0.0702 & 0.0807 \\
\hline
\end{tabular}


Table 1. Cont.

\begin{tabular}{cccccc}
\hline \multirow{2}{*}{ Date } & \multirow{2}{*}{ Wavelength $(\mathbf{n m})$} & \multicolumn{3}{c}{ Surface Reflectance at Different AERONET Sites } \\
\cline { 3 - 5 } & & Beijing & XiangHe & Beijing_RADI & Beijing_CAMS \\
\hline \multirow{3}{*}{ July 2012 } & 645 & 0.0615 & 0.0676 & 0.0563 & 0.0471 \\
& 858 & 0.1570 & 0.2475 & 0.2093 & 0.1383 \\
& 470 & 0.0325 & 0.0396 & 0.0238 & 0.0148 \\
August 2012 & 555 & 0.0560 & 0.0667 & 0.0649 & 0.0463 \\
& 645 & 0.0688 & 0.0490 & 0.0637 & 0.0639 \\
& 858 & 0.1443 & 0.2245 & 0.1849 & 0.1402 \\
& 470 & 0.0356 & 0.0257 & 0.0305 & 0.0304 \\
& 555 & 0.0630 & 0.0466 & 0.0661 & 0.0571 \\
\hline
\end{tabular}

\section{AOD Retrieval}

\subsection{Data}

In this study, 20 cloud-free Landsat 8 Operational Land Imager (OLI) images were acquired between May 2013 and October 2014 in the Beijing area for AOD retrieval using the new algorithm (Table 2). The Landsat 8 satellite was launched by the United States National Aeronautics and Space Administration (NASA) in February 2013. Landsat 8 OLI data have eight multi-spectral bands with a spatial resolution of $30 \mathrm{~m}$ and a panchromatic band with $15 \mathrm{~m}$ resolution. The satellite covers the entire earth every 16 days. Detailed parameters are shown in Table 3.

Table 2. Landsat 8 Operational Land Imager (OLI) images used for AOD retrieval.

\begin{tabular}{cc}
\hline Landsat 8 OLI (Date) & Landsat 8 OLI (Date) \\
\hline 12 May 2013 & 29 April 2014 \\
13 June 2013 & 15 May 2014 \\
31 July 2013 & 31 May 2014 \\
1 September 2013 & 16 June 2014 \\
3 October 2013 & 18 July 2014 \\
4 November 2013 & 3 August 2014 \\
20 November 2013 & 19 August 2014 \\
6 December 2013 & 4 September 2014 \\
1 August 2014 & 20 September 2014 \\
13 April 2014 & 6 October 2014 \\
\hline
\end{tabular}

Table 3. Parameters of the Landsat 8 OLI sensor.

\begin{tabular}{|c|c|c|}
\hline Parameters & \multicolumn{2}{|c|}{ Landsat 8 OLI Sensor } \\
\hline \multirow{8}{*}{ Spectral range } & Panchromatic & $0.50-0.68 \mu \mathrm{m}$ \\
\hline & \multirow{7}{*}{ Multi-spectral } & Aerosol $0.43-0.45 \mu \mathrm{m}$ \\
\hline & & Blue $0.45-0.51 \mu \mathrm{m}$ \\
\hline & & Green $0.53-0.59 \mu \mathrm{m}$ \\
\hline & & Red $0.64-0.67 \mu \mathrm{m}$ \\
\hline & & NIR $0.85-0.88 \mu \mathrm{m}$ \\
\hline & & SWIR1 1.57-1.65 $\mu \mathrm{m}$ \\
\hline & & SWIR2 2.11-2.29 $\mu \mathrm{m}$ \\
\hline \multirow{2}{*}{ Spatial resolution } & Panchromatic & $15 \mathrm{~m}$ \\
\hline & Multi-spectral & $30 \mathrm{~m}$ \\
\hline Swath width & \multicolumn{2}{|c|}{$185 \mathrm{~km}$} \\
\hline Temporal resolution & \multicolumn{2}{|c|}{16 days } \\
\hline
\end{tabular}


The DN (Digital Number) values of Landsat 8 OLI data can be converted to TOA spectral reflectance using the coefficients of the reflectance rescaling factors (Equations (2) and (3)) as follows:

$$
\rho_{\lambda}=M Q_{c a l}+A
$$

and

$$
\rho^{*}=\frac{\rho_{\lambda}}{\cos \left(\theta_{S Z}\right)}=\frac{\rho_{\lambda}}{\sin \left(\theta_{S E}\right)}
$$

where $\rho_{\lambda}$ is the TOA reflectance without correction for the solar angle, $Q_{c a l}$ is the quantized and calibrated standard DN value, $M$ is the band-specific multiplicative rescaling factor, $A$ is the band-specific additive rescaling factor, $\theta_{\mathrm{SZ}}$ is the local solar elevation angle, $\theta_{\mathrm{SE}}$ is the local sun elevation angle, and $\rho^{*}$ is the TOA reflectance.

Figure 3 shows the Landsat 8 OLI standard false color images (RGB: 543) in the Beijing area for 12 May 2013, 13 April 2014, 4 September 2014 and 6 October 2014. The land cover includes water, vegetation and urban areas. Water and vegetation exhibit a low LSR in the blue band, whereas urban areas exhibit a high LSR. Figure 4 shows the monthly LSR distribution in the blue band of the MODIS data that corresponds with the Landsat 8 OLI images in Figure 3. Figure 4 demonstrates that the LSR in the blue band of urban areas is higher than that of vegetation and water. Although the LSR of urban areas is relatively high, it is still lower than 0.15 in the blue band.

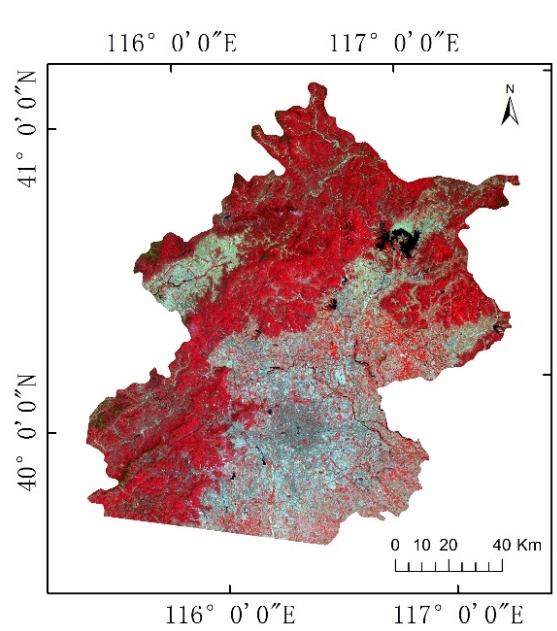

(a) 12 May 2013

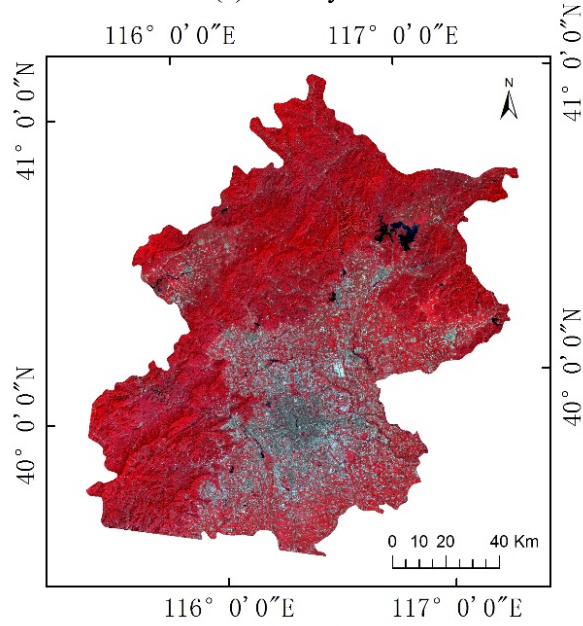

(c) 4 September 2014

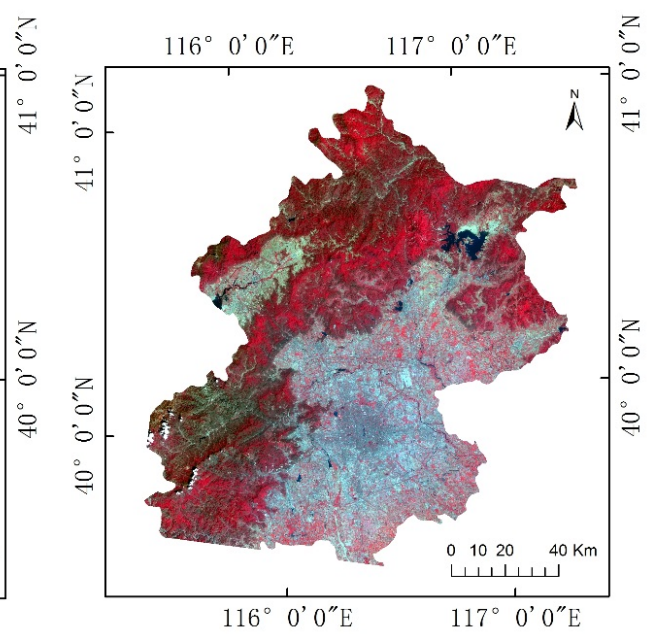

(b) 13 April 2014

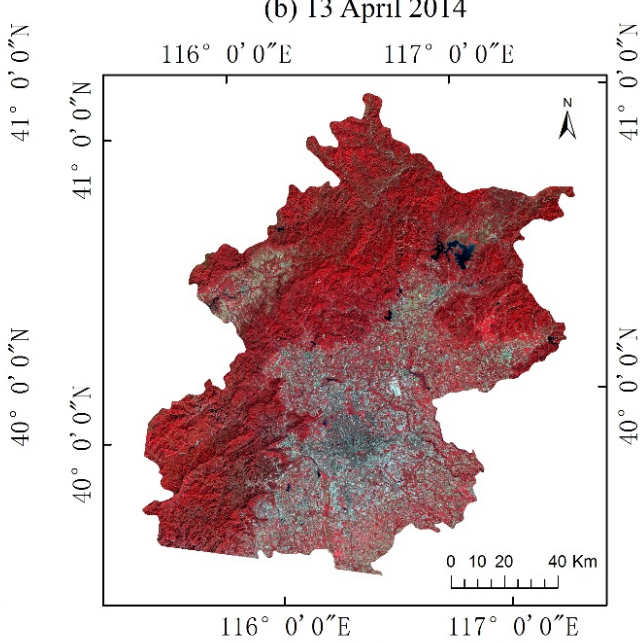

(d) 6 October 2014

Figure 3. Landsat 8 OLI false color images of the Beijing area $(R, G, B=5,4,3)$. (a) 12 May 2013; (b) 13 April 2014; (c) 4 September 2014; (d) 6 October 2014. 


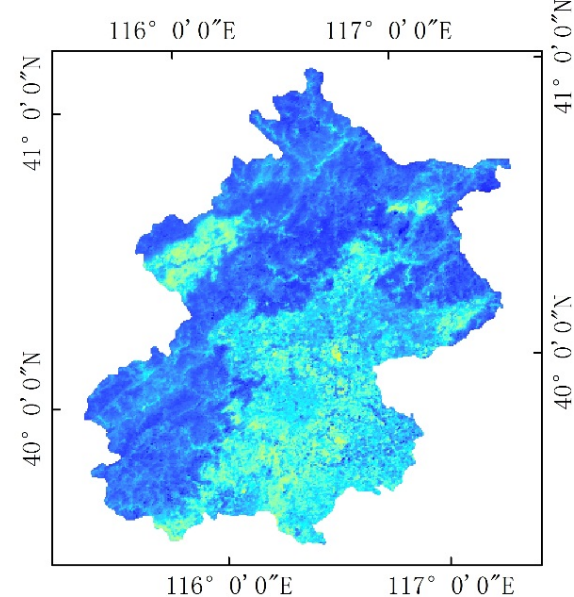

(a) May 2012

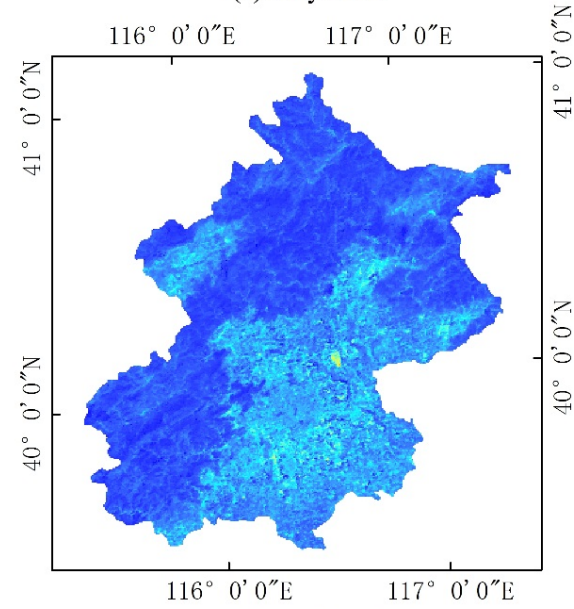

(c) September 2012

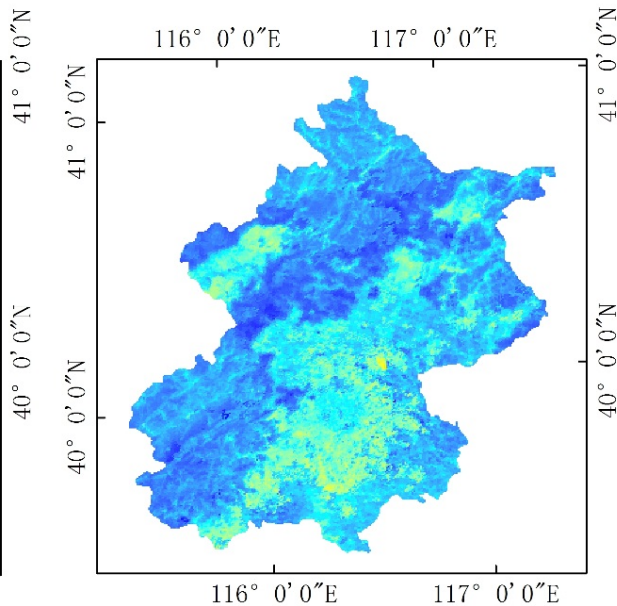

(b) April 2012
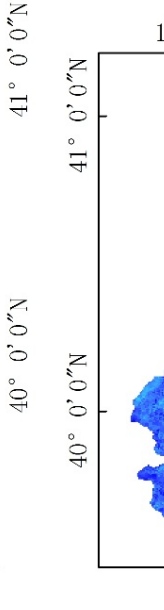
$6^{\circ}$ O' 0"E $117^{\circ} 0^{\prime} 0^{\prime \prime} \mathrm{E}$ 71
5
10
0 $\stackrel{N}{\Lambda}$
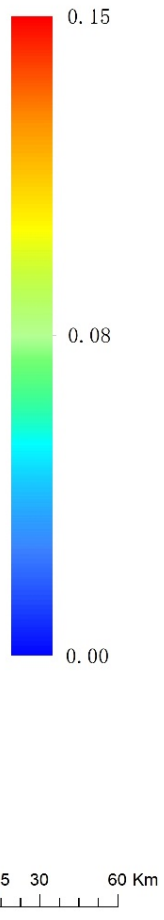

(d) October 2012

Figure 4. Corresponding MODerate-resolution Imaging Spectroradiometer (MODIS) surface reflectance images of in the blue band $(0.47 \mu \mathrm{m})$ in the Beijing area corresponding to the Landsat 8 OLI images in Figure 3. (a) May 2012; (b) April 2012; (c) September 2012; (d) October 2012.

\subsection{The Look-Up Table}

To quickly and conveniently calculate AOD using the radiative transfer equation, a Look-Up Table (LUT) was constructed using the $6 \mathrm{~S}$ model (Second Simulation of the Satellite Signal in the Solar Spectrum). The $6 \mathrm{~S}$ code is a basic radiative transfer code used for simulations of satellite observation that considers elevated targets and molecular and aerosol scattering and gaseous absorption (including $\mathrm{H}_{2} \mathrm{O}, \mathrm{O}_{3}, \mathrm{O}_{2}$ and $\mathrm{CO}_{2}$ ) [33]. It has been used for calculation of LUTs for AOD retrieval from many sensors $[12,20,26,34]$. The parameters in the LUT include thirteen solar and sensor zenith angles ranging from $0^{\circ}$ to $72^{\circ}$, with an interval of $6^{\circ}$, and nineteen solar and sensor azimuth angles ranging from $0^{\circ}$ to $180^{\circ}$, with an interval of $10^{\circ}$. The composition of the aerosol model is constantly changing in different areas, and the aerosol model selection is one of the key issues in aerosol retrieval using satellite remote sensing [35]. Therefore, the aerosol model is an important parameter that affects the precision of AOD retrieval and must be considered carefully. Previous research shows that continental aerosol can broadly describe the aerosol condition for the research area [34,36,37]. Therefore, the continental aerosol model is selected in the current study. Table 4 shows the detailed optical properties for continental aerosol model and Figure 5 is the phase function at $550 \mathrm{~nm}$ when AOD is 0.5 . Sixteen values of $\operatorname{AOD}(0,0.01,0.05,0.1,0.2,0.3,0.4,0.5,0.6,0.7,0.8,0.9,1.0,1.2,1.5$, and 2.0) and default values from the atmospheric model in $6 \mathrm{~S}$ for the other atmospheric parameters-including ozone and water vapor, which are not very sensitive in the blue band-are selected. The surface reflectance 
ranges from 0.0 to 0.15 , with an interval of 0.01 set in the LUT. Aerosol parameters, including solar and sensor zenith angles, solar and sensor azimuth angles, continental aerosol model, AOD and surface reflectance, are chosen to construct the LUT under different observations.

Table 4. Optical properties of continental model used in AOD retrieval.

\begin{tabular}{cccccccc}
\hline Model & Mode & $\mathbf{r}_{\mathbf{v}}(\mu \mathbf{m})$ & $\sigma$ & $\mathbf{V}_{\mathbf{0}}\left(\mu \mathbf{m}^{3} /\left(\mu \mathbf{m}^{2}\right)\right.$ & $\mathbf{k}$ & $\mathbf{S S A}$ & $\mathbf{g}$ \\
\hline \multirow{4}{*}{ Continental } & Soluble & 0.170 & 1.09 & 3.05 & $1.53-0.006 \mathrm{i}$ & & \\
& Dust & 17.6 & 1.09 & 7.36 & $1.53-0.008 \mathrm{i}$ & 0.89 & 0.63 \\
& Soot & 0.050 & 0.69 & 0.11 & $1.75-0.440 \mathrm{i}$ & & \\
\hline
\end{tabular}

Note: These parameters are the mean radius $\left(\mathrm{r}_{\mathrm{v}}\right)$, standard deviation $(\sigma)$ of the volume distribution, total volume of the model $\left(\mathrm{V}_{0}\right)$, complex refractive index $(\mathrm{k})$, single scattering albedo (SSA) and asymmetry parameter $(\mathrm{g})$, defined at $550 \mathrm{~nm}$.

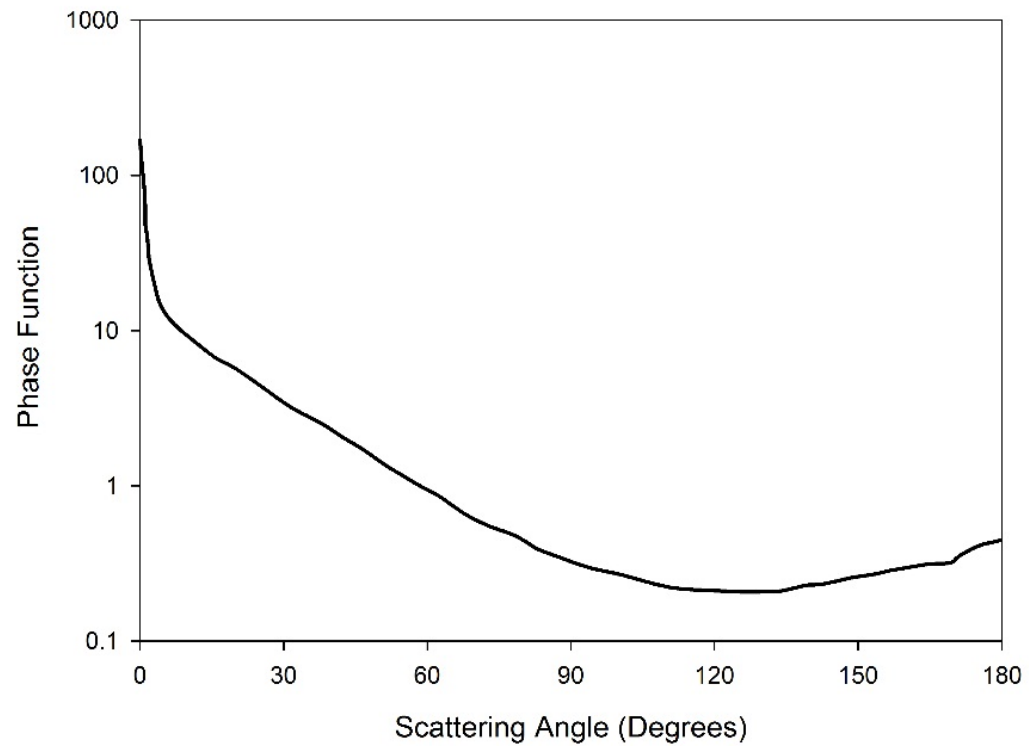

Figure 5. Plot of phase function at $550 \mathrm{~nm}$ for continental aerosol model (AOD = 0.5).

\subsection{AOD Retrieval}

The TOA reflectance of the selected Landsat 8 OLI images was used to retrieve AOD, supported by the corresponding MOD09A1 data. Because of the different spatial resolutions of these two types of data, the Landsat 8 OLI images were resampled to a $500 \mathrm{~m}$ resolution.

\section{Results and Discussion}

\subsection{Characteristics of AOD Spatial Distribution}

Figure 6 shows the AOD in the Beijing area retrieved from Landsat 8 OLI images at $500 \mathrm{~m}$ resolution. Four images with different aerosol loadings were selected to display the aerosol distribution. These results demonstrate that the new algorithm can achieve a continuous AOD distribution, even in the center of urban areas with buildings and roads, which have a high reflectance and complex structure. Conventional retrieval methods have limitations for AOD retrieval for these complex areas. The new algorithm describes the aerosol distribution and variability in greater detail at high spatial resolution $(500 \mathrm{~m})$ than the current operational MOD04 Level 2 AOD product $(10 \mathrm{~km})$. 


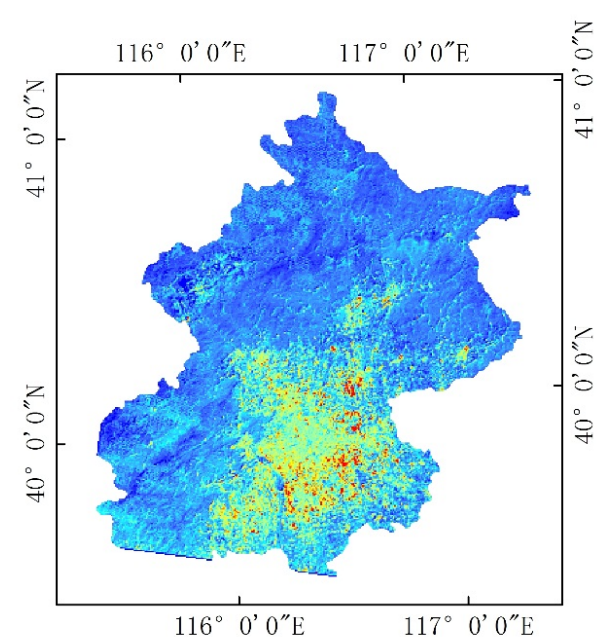

(a) 12 May 2013

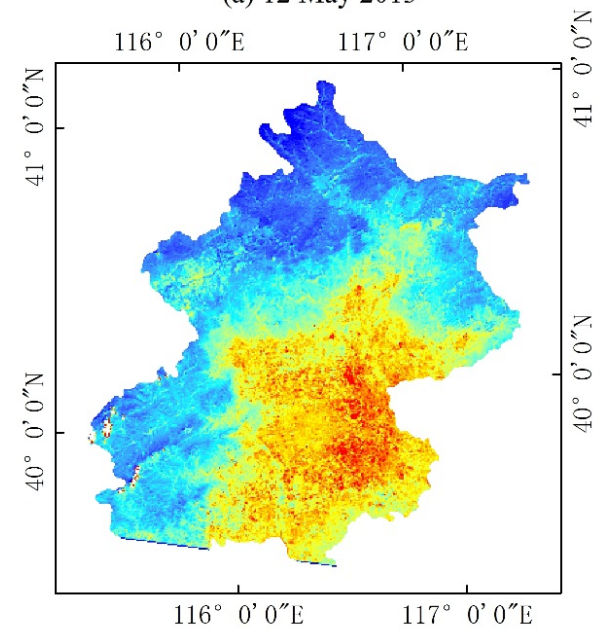

(c) 4 September 2014

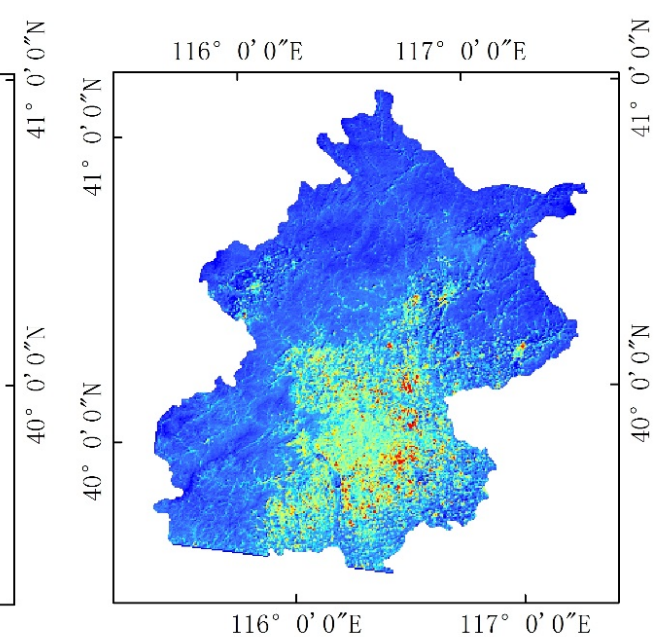

(b) 13 April 2014

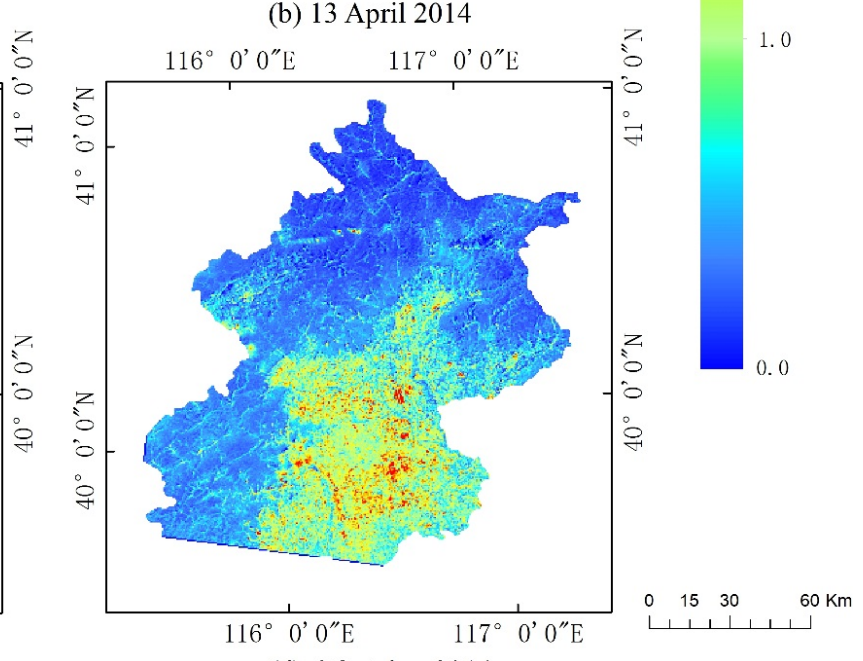

(d) 6 October 2014
$\bigwedge^{N}$

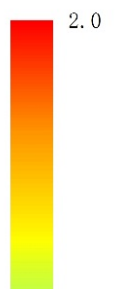

0

(a) 12 May 2013; (b) 13 April 2014;

\subsection{Comparison with AERONET Measurements}

AOD measurements from AErosol RObotic NETwork (AERONET) stations were used to validate the AOD retrieved from Landsat 8 OLI images. The AERONET stations comprise a group of ground-based remote sensing aerosol sites established by NASA, the French Centre National de la Recherché Scientifique, and numerous other partners. The program provides a long-term, continuous and readily accessible public database of optical, microphysical and radiative aerosol properties for aerosol research. The network has standardized instruments, calibration, processing and distribution, providing an AOD accuracy of $\sim 0.01$ in the absence of unscreened clouds in the visible and near-infrared ranges [38,39]. AOD products provided by AERONET at a temporal resolution every $15 \mathrm{~min}$ are categorized in various levels: Level 1.0 (unscreened), Level 1.5 (cloud-screened), and Level 2.0 (cloud-screened and quality-assured) [40-42]. The Level 2.0 (for Beijing site) and Level 1.5 (the other sites) AOD products were used for validation purpose. To obtain the AOD at $550 \mathrm{~nm}$, the AODs at $440 \mathrm{~nm}, 500 \mathrm{~nm}$, and $675 \mathrm{~nm}$ from AERONET were interpolated using the Angstrom Exponent method [43-45], which uses the equation

$$
\tau_{a}(\lambda)=\beta \lambda^{-\alpha}
$$


where $\tau_{a}(\lambda)$ is the AOD at $\lambda, \lambda$ is the wavelength, $\beta$ is the turbidity factor, and $\alpha$ is the band index, which are written as

$$
\alpha=-\frac{\ln \left(\tau_{a}\left(\lambda_{1}\right) / \tau_{a}\left(\lambda_{2}\right)\right)}{\ln \left(\lambda_{1} / \lambda_{2}\right)}
$$

and

$$
\beta=\frac{\tau_{a}\left(\lambda_{1}\right)}{\lambda_{1}^{-\alpha}}
$$

The Beijing, Beijing_CAMS, Beijing_RADI, and XiangHe stations, which are located in areas with relatively bright surfaces, were chosen to validate the retrieved AOD. Figure 7 compares the AOD retrieved from Landsat 8 OLI images with the AERONET AOD. The retrieved AOD ranges from 0.05 to 2.0, and its wide distribution meets the requirements for validating retrieval results under different aerosol concentrations.

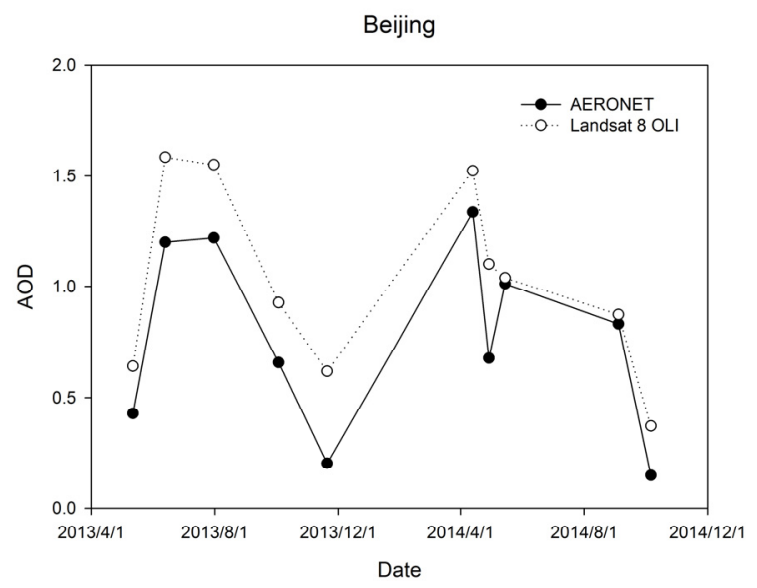

(a)

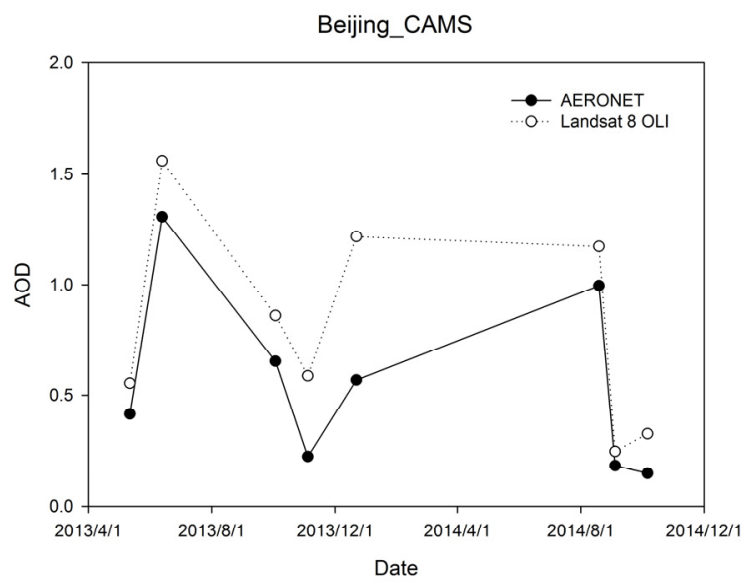

(c)

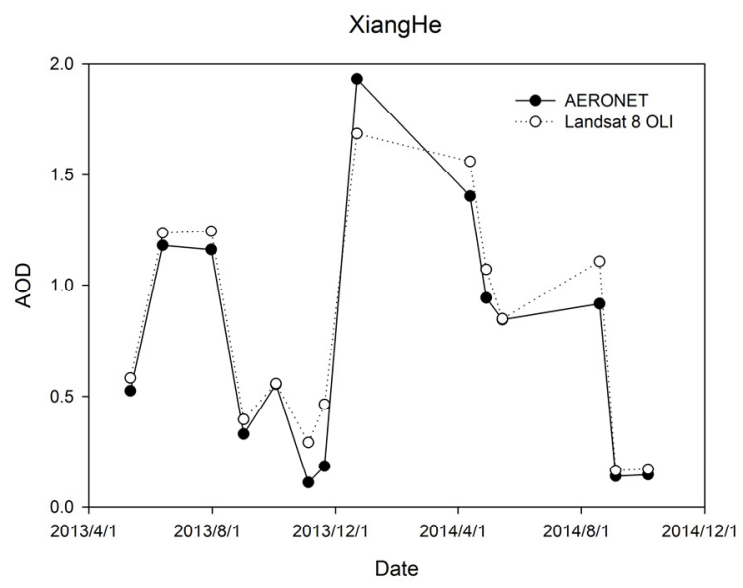

(b)

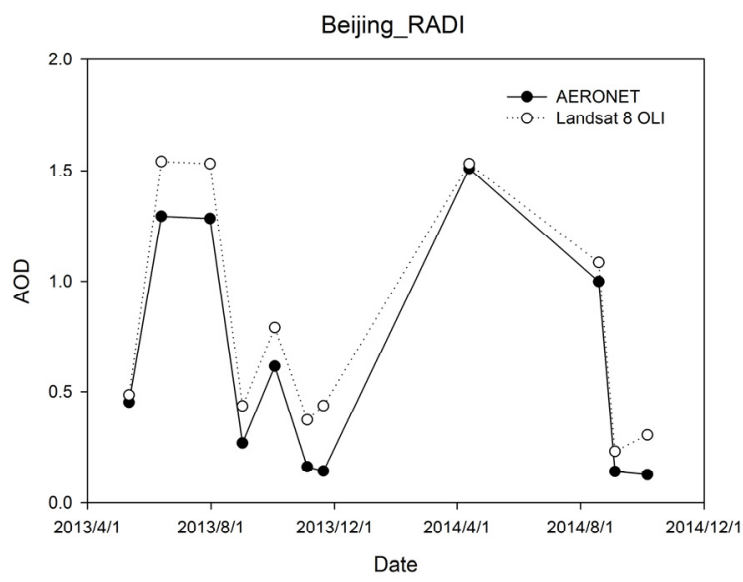

(d)

Figure 7. Comparison between AOD retrieved with the proposed algorithm and AOD measured by AERONET stations at $550 \mathrm{~nm}$ : (a) Beijing site; (b) Xianghe site; (c) Beijing_CAMS site and (d) Beijing_RADI site.

AODs obtained from AERONET within \pm 30 min of the Landsat 8 OLI overpass times were compared with the AODs retrieved from the Landsat 8 OLI images over an area of $3 \times 3$ pixels $\left(1.5 \mathrm{~km}^{2}\right.$ area) centered on the AERONET sites. This validation shows that the retrieved AODs are consistent with the AODs from the AERONET stations. When the AOD $<0.6$, the average absolute error is approximately 0.143 , and when the AOD $>0.6$, the average absolute error is approximately 0.206 
(Table 5). These results indicate that the proposed algorithm can retrieve AOD from Landsat 8 OLI data with an acceptable accuracy and stability, with $67.44 \%$ falling within the expected error.

Table 5. Validation of retrieved AOD.

\begin{tabular}{cccccc}
\hline AODs & Counts & $\mathbf{R}^{\mathbf{2}}$ & Absolute Error & Relative Error/\% & $\mathbf{r} / \%$ \\
\hline AOD $<0.6$ & 18 & 0.5254 & 0.143 & 84.30 & 50.00 \\
AOD $>0.6$ & 25 & 0.7911 & 0.206 & 34.22 & 80.00 \\
Total & 43 & 0.9059 & 0.182 & 53.19 & 67.44 \\
\hline
\end{tabular}

Note: $r$ is the proportion within the expected error.

\subsection{Comparison with Standard Aerosol Products}

For comparison purposes, the MOD04 Level 2 operational aerosol product corresponding with the same time and area as the AOD retrieved from Landsat 8 OLI images was obtained. The MOD04 product defines different aerosol type models, including absorbing (SSA 0.85), moderately absorbing (SSA 0.90) and weakly absorbing (SSA 0.95), through the AERONET sites in a global map for each season [46]. Figure 8 shows the validation of the AOD retrieved from two types of satellite data with the AOD measurements from AERONET stations. Validation results show that the AOD retrieved from Landsat 8 OLI images by the algorithm outlined in this paper can achieve a higher consistency with the AODs measured by AERONET $\left(\mathrm{R}^{2} \sim 0.9362\right)$, with a smaller RMSE $(\sim 0.1091)$ to that of the MOD04 product $\left(\mathrm{R}^{2} \sim 0.6624\right.$, RMSE $\left.\sim 0.2509\right)$ over Beijing areas. However, differences in the AOD retrievals can be attributable not only to surface reflectance differences but also to assumptions about the aerosol models utilized in the retrievals.

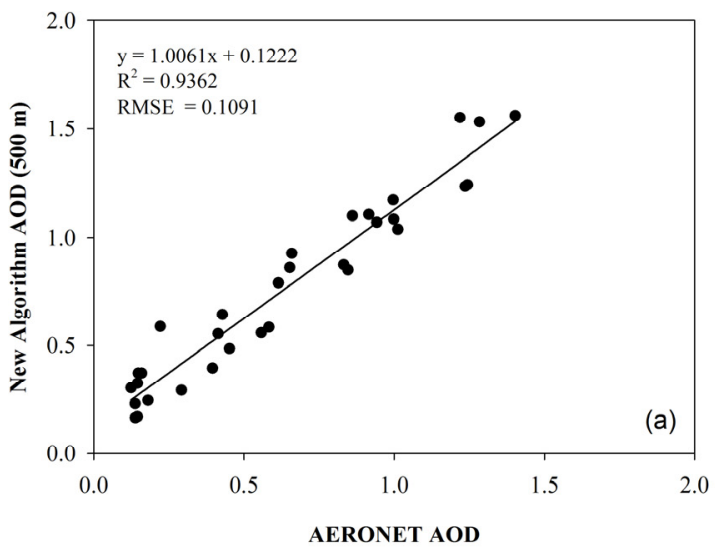

(a)

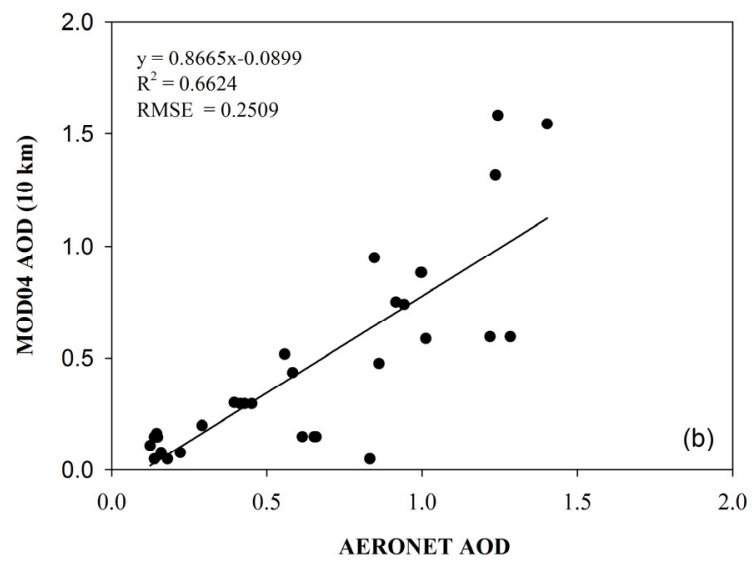

(b)

Figure 8. Comparison between AOD retrieved from Landsat 8 OLI images, the MODIS AOD product (MOD04) and the AERONET AOD measurements. The left plot is used to validate the new algorithm, and the right is used for the MOD04 product: (a) New algorithm and (b) MOD04 product.

\section{Conclusions}

Many methods have been developed for Aerosol Optical Depth (AOD) retrieval, and many aerosol products from different sensors have been produced based on these methods. These have enhanced our ability to characterize the spatial distribution of global aerosol properties. However, most of the methods focus on AOD retrieval over dark areas, which leads to poor AOD distribution over urban, arid and semi-arid areas. Conventional methods for AOD retrieval over areas with low reflectance cannot be applied to AOD retrieval over bright areas because there are fewer identifying properties of aerosols in the satellite signal, and the land structure is more complex. Methods of estimating Land 
Surface Reflectance (LSR) based on the relationship between visible and near-infrared bands cannot be used in high-reflectance areas.

In this paper, a new method for retrieving AOD from Landsat 8 Operational Land Imager (OLI) images over urban areas with high surface reflectance in Beijing is proposed. MODIS (MODerate resolution Imaging Spectroradiometer) surface reflectance products were used to assist in estimating the LSR of the Landsat 8 OLI images that was necessary for AOD retrieval. A Look-Up Table (LUT) was constructed based on the $6 \mathrm{~S}$ (Second Simulation of the Satellite Signal in the Solar Spectrum) radiance transfer code. The retrieved AODs were validated using AOD measurements from AERONET and compared with MOD04 Level 2 AOD observations at $10 \mathrm{~km}$ resolution. The results show that this new method achieves reasonable precision in AOD retrieval and describes the actual characteristics of the aerosol distribution in more detail than standard methods.

The following aspects of this new method should be improved in future studies. (1) This paper focuses on estimation of the LSR to achieve AOD retrieval from Landsat 8 OLI data. However, the aerosol model is also a key factor that influences the precision of the AOD retrieval, and the use of a continental model will create some error; (2) The surface reflectance depends on the solar zenith and satellite viewing geometry. The Landsat 8 OLI and MODIS data have different geometries, and the characteristics of the BRDF (Bi-directional Reflectance Distribution Function) will induce some error in the LSR estimation; (3) Because of the time difference between the Landsat 8 OLI and the MODIS data, the changes in land characteristics are an additional factor that could lead to errors in the LSR calculation; (4) The influence of the non-Lambertian nature of real-world surfaces and phase function uncertainty should be estimated. These factors can introduce errors in the AOD retrieval and should be examined in the future.

Acknowledgments: The authors thank the foundation of the Outstanding Youth Fund of Shandong Province (JQ201211) and the Graduate Innovation Fund of Shandong University of Science and Technology (YC150103). We also thank NASA for providing the MODIS and Landsat 8 OLI data, and H.-B. Chen for establishing and maintaining the AERONET sites used in this study.

Author Contributions: Lin Sun and Jing Wei performed the new AOD algorithm research and prepared the paper. Muhammad Bilal provided advice and suggestions. Xinpeng Tian, Chen Jia, Yamin Guo and Xueting Mi helped with the ground-based data and satellite remote sensing data collection and processing.

Conflicts of Interest: The authors declare no conflict of interest.

\section{References}

1. Colvile, R.N.; Hutchinson, E.J.; Warren, R.F. The transport sector as a source of air pollution. Atmos. Environ. 2001, 35, 1537-1565. [CrossRef]

2. Espinosa, A.J.F.; Rodriguez, M.T.; de la Rosa, F.J.B.; Sánchez, J.C.J. A chemical speciation of trace metals for fine urban particles. Atmos. Environ. 2002, 36, 773-780. [CrossRef]

3. Xu, X.D. Dynamic issues of urban atmospheric pollution models. J. Appl. Meteorol. Sci. 2002, 13, 1-12. [CrossRef]

4. Marcazzan, G.M.; Ceriani, M.; Valli, G.; Vecchi, R. Source apportionment of PM10 and PM2.5 in Milan (Italy) using receptor modelling. Sci. Total Environ. 2003, 317, 137-147. [CrossRef]

5. Kocifaj, M.; Horvath, H.; Jovanović, O.; Gangl, M. Optical properties of urban aerosols in the region Bratislava-Vienna I. Methods and tests. Atmos. Environ. 2006, 40, 1922-1934. [CrossRef]

6. Huang, D.S.; Xu, J.H.; Zhang, S.Q. Valuing the health risks of particulate air pollution in the Pearl River Delta, China. Environ. Sci. Policy 2012, 15, 38-47. [CrossRef]

7. Riffler, M.; Popp, C.; Hauser, A.; Fontana, F.; Wunderle, S. Validation of a modified AVHRR aerosol optical depth retrieval algorithm over Central Europe. Atmos. Meas. Tech. 2010, 3, 1255-1270. [CrossRef]

8. Sayer, A.M.; Hsu, N.C.; Bettenhausen, C.; Jenong, M.J.; Holben, B.N.; Zhang, J. Global and regional evaluation of over-land spectral aerosol optical depth retrievals from SeaWiFS. Atmos. Meas. Tech. 2012, 5, 1761-1778. [CrossRef]

9. Hsu, N.C.; Jeong, M.-J.; Bettenhausen, C.; Sayer, A.M.; Hansell, R.; Seftor, C.S. Enhanced deep blue aerosol retrieval algorithm: The second generation. J. Geophys. Res. Atmos. 2013, 118, 9296-9315. [CrossRef] 
10. Levy, R.C.; Mattoo, S.; Munchak, L.A.; Rember, L.A.; Sayer, A.M.; Hsu, N.C. The Collection 6 MODIS aerosol products over land and ocean. Atmos. Meas. Tech. 2013, 6, 159-259. [CrossRef]

11. Kaufman, Y.J.; Sendra, C. Algorithm for automatic atmospheric corrections to visible and near-IR satellite imagery. Int. J. Remote Sens. 1988, 9, 1357-1381. [CrossRef]

12. Kaufman, Y.J.; Tanré, D.; Remer, L.A.; Vermote, E.F.; Chu, A.; Holben, B.N. Operational remote sensing of tropospheric aerosol over land from EOS moderate resolution imaging spectroradiometer. J. Geophys. Res. 1997, 102, 17051-17067. [CrossRef]

13. Remer, L.A.; Kaufman, Y.J.; Tanréx, D.; Mattoo, S.; Chu, D.A.; Martins, J.V.; Li, R.R.; Ichoku, C.; Levy, R.C.; Kleidman, R.G.; et al. The MODIS aerosol algorithm, products, and validation. J. Atmos. Sci. 2005, 62, 947-973. [CrossRef]

14. Kaufman, Y.J. Satellite sensing of aerosol absorption. J. Geophys. Res. Atmos. 1987, 92, 4307-4317. [CrossRef]

15. Vermote, E.F.; Vermeulen, A. MODIS ATBD: Atmospheric Correction Algorithm: Spectral Reflectances (MOD09), Version 4.0, April 1999. Available online: http://modis.gsfc.nasa.gov/data/atbd/ atbd_mod08.pdf (accessed on 30 June 2015).

16. Levy, R.C.; Remer, L.A.; Martins, J.V.; Plana-Fattori, A.; Redemann, J.; Wenny, B. Evaluation of the MODIS aerosol retrievals over ocean and land during CLAMS. J. Atmos. Sci. 2005, 62, 974-992. [CrossRef]

17. Levy, R.C.; Remer, L.A.; Mattoo, S.; Vermote, E.F.; Kaufman, Y.J. Second-generation operational algorithm: Retrieval of aerosol properties over land from inversion of moderate resolution imaging spectroradiometer spectral reflectance. J. Geophys. Res. Atmos. 2007, 112, 1-21. [CrossRef]

18. Jackson, J.M.; Liu, H.; Laszlo, I.; Kondragunta, S.; Remer, L.A.; Huang, J.; Huang, H.C. Suomi-NPP VIIRS aerosol algorithms and data products. J. Geophys. Res. Atmos. 2013, 118, 12673-12689. [CrossRef]

19. Munchak, L.A.; Levy, R.C.; Mattoo, S.; Remer, L.A. Modis 3 km aerosol product: Applications over land in an urban/suburban region. Atmos. Meas. Tech. 2013, 6, 1747-1759. [CrossRef]

20. Tanré, D.; Deschamps, P.Y.; Devaux, C.; Herman, M. Estimation of Saharan aerosol optical thickness from blurring effects in thematic mapper data. J. Geophys. Res. Atmos. 1988, 93, 15955-15964. [CrossRef]

21. Holben, B.N.; Vermote, E.; Kaufman, Y.J.; Tanré, D.; Kalb, V. Aerosol retrieval over land from AVHRR data-application for atmospheric correction. IEEE Trans. Geosci. Remote Sens. 1992, 30, 212-222. [CrossRef]

22. Liu, G.R.; Chen, A.J.; Liu, T.H.; Kuo, T.H. Applying SPOT data to estimate the aerosol optical depth and air quality. Environ. Modell. Softw. 2002, 17, 3-9. [CrossRef]

23. Lyapustin, A.; Wang, Y.; Laszlo, I.; Kahn, R.; Korkin, S.; Remer, L.A.; Levy, R.C.; Reid, J.S. Multiangle implementation of atmospheric correction (MAIAC): 2. Aerosol algorithm. J. Geophys. Res. Atmos. 2011, 116, 613-632. [CrossRef]

24. Bilal, M.; Nichol, J.E.; Bleiweiss, M.P.; Dubois, D. A Simplified high resolution MODIS Aerosol Retrieval Algorithm (SARA) for use over mixed surfaces. Remote Sens. Environ. 2013, 136, 135-145. [CrossRef]

25. Bilal, M.; Nichol, J.E.; Chan, P.W. Validation and accuracy assessment of a Simplified Aerosol Retrieval Algorithm (SARA) over Beijing under low and high aerosol loadings and dust storms. Remote Sens. Environ. 2014, 153, 50-60. [CrossRef]

26. Hsu, C.N.; Tsay, S.C.; King, M.D.; Herman, J.R. Aerosol properties over bright-reflecting source regions. IEEE Trans. Geosci. Remote Sens. 2004, 42, 557-569. [CrossRef]

27. Hsu, C.N.; Tsay, S.C.; King, M.D.; Herman, J.R. Deep blue retrievals of Asian aerosol properties during ACE-Asia. IEEE Trans. Geosci. Remote Sens. 2006, 44, 3180-3195. [CrossRef]

28. Hansen, M.C.; Roy, D.P.; Lindquist, E.; Adusei, B.; Justuce, C.O.; Altstatt, A. A method for integrating MODIS and Landsat data for systematic monitoring of forest cover and change in the Congo Basin. Remote Sens. Environ. 2008, 112, 2495-2513. [CrossRef]

29. Hilker, T.; Wulder, M.A.; Coops, N.C.; Linke, J.; McDermid, G.; Masek, J.G.; Gao, F.; White, J.C. A new data fusion model for high spatial-and temporal-resolution mapping of forest disturbance based on Landsat and MODIS. Remote Sens. Environ. 2009, 113, 1613-1627. [CrossRef]

30. Xin, Q.; Olofsson, P.; Zhu, Z.; Tan, B.; Woodcock, C.E. Toward near real-time monitoring of forest disturbance by fusion of MODIS and Landsat data. Remote Sens. Environ. 2013, 135, 234-247. [CrossRef]

31. Roy, D.P.; Qin, Y.; Kovalskyy, V.; Vermote, E.F.; Ju, J.; Egorov, A.; Hansen, M.C.; Kommareddy, I.; Yan, L. Conterminous United States demonstration and characterization of MODIS-based Landsat ETM+ atmospheric correction. Remote Sens. Environ. 2014, 140, 433-449. [CrossRef] 
32. Vermote, E.F.; Kotchenova, S.Y. MOD09 User's Guide (J/OL). Available online: http:/ / modis-sr.ltdri.org (accessed on 30 June 2015).

33. Vermote, E.F.; Tanré, D.; Deuze, J.L.; Herman, M.; Morcrette, J.J. Second Simulation of a Satellite Signal in the Solar Spectrum-Vector (6SV). Available online: http:/ /6s.ltdri.org/files/tutorial/6S_Manual_Part_1.pdf (accessed on 30 June 2015).

34. He, J.; Zha, Y.; Zhang, J.; Gao, J.; Li, Y.; Chen, X. Retrieval of aerosol optical thickness from HJ-1 CCD data based on MODIS-derived surface reflectance. Int. J. Remote Sens. 2015, 36, 882-898. [CrossRef]

35. Chen, L.F. Quantitative Study and Application of Aerosol Remote Sensing Retrieval; Science Press: Beijing, China, 2011. (In Chinese)

36. Sun, L.; Sun, C.K.; Liu, Q.H.; Zhong, B. Aerosol optical depth retrieval by HJ-1/CCD supported by MODIS surface reflectance data. Sci. China Earth Sci. 2010, 53, 74-80.

37. Wang, Z.T.; Li, Q.; Wang, Q.; Li, S.S.; Chen, L.F.; Zhou, C.Y.; Zhang, L.J.; Xu, Y.J. HJ-1 terrestrial aerosol data retrieval using deep blue algorithm. J. Remote Sens. 2012, 16, 596-610.

38. Chew, B.N.; Campbell, J.R.; Reid, J.S.; Giles, D.M.; Welton, E.J.; Salinas, S.V.; Liew, S.C. Tropical cirrus cloud contamination in sun photometer data. Atmos. Environ. 2011, 45, 6724-6731. [CrossRef]

39. Eck, T.F.; Holben, B.N.; Reid, J.S.; Dubovik, O.; Smirnov, A.; O’Neill, N.T.; Slutsker, I.; Kinne, S. Wavelength dependence of the optical depth of biomass burning, urban, and desert dust aerosols. J. Geophys. Res. Atmos. 1999, 104, 31333-31349. [CrossRef]

40. Holben, B.N.; Tanré, D.; Smirnov, A.; Eck, T.F.; Slutsker, I.; Abuhassan, N.; Newcomb, W.W.; Schafer, J.S.; Chatenet, B.; Lavenu, F.; et al. An emerging ground-based aerosol climatology: Aerosol optical depth from AERONET. J. Geophys. Res. Atmos. 2001, 106, 12067-12097. [CrossRef]

41. Holben, B.N.; Eck, T.F.; Slutsker, I.; Tanre, D.; Buis, J.P.; Setzer, A.; Vermote, E.; Reagan, J.A.; Kaufman, Y.J.; Nakajima, T.; et al. AERONET-A federated instrument network and data archive for aerosol characterization. Remote Sens. Environ. 1998, 66, 1-16. [CrossRef]

42. Smirnov, A.; Holben, B.N.; Eck, T.F.; Dubovik, O.; Slutsker, I. Cloudscreening and quality control algorithms for the AERONET database. Remote Sens. Environ. 2000, 73, 337-349. [CrossRef]

43. Dubovik, O.; King, M.D. A flexible inversion algorithm for retrieval of aerosol optical properties from sun and sky radiance measurements. J. Geophys. Res. Atmos. 2000, 105, 20673-20696. [CrossRef]

44. Li, Z.Q.; Niu, F.; Lee, K.H.; Xin, J.Y.; Hao, W.M.; Nordgren, B.; Wang, Y.S.; Wang, P.C. Validation and understanding of Moderate resolution imaging spectroradiometer aerosol products (C5) using ground-based measurements from the handheld Sun photometer network in China. J. Geophys. Res. Atmos. 2007, 112, 365-371. [CrossRef]

45. Ångström, A. The parameters of atmospheric turbidity. Tellus 1964, 16, 64-75. [CrossRef]

46. Levy, R.C. Retrieval of Tropospheric Aerosol Properties over Land from Visible and Near-Infrared Spectral Reflectance: Application over Maryland. Ph.D. Thesis, University of Maryland, College Park, MD, USA, 2007. 